\title{
Effects of immigration on population growth and structures in Greece - A spatial approach
}

\author{
Anastasia Kostaki, Byron Kotzamanis and Michail Agorastakis*
}

\begin{abstract}
From the early 1990s, Greece has been experiencing a strong immigration flow consisting of various nationality groups with different demographic profiles and structures. The immigrant population is not uniformly distributed spatially and consists of various nationality groups with different demographic behaviours. Therefore, the examination of the implications of immigration on the population size and structure at a low geographical level, according to the nationality composition of the foreign population, is useful in finding population structures which are impossible to observe otherwise. This paper examines the impact of immigration on the population size, age and sex structure of the population in Greek municipalities. In order to do this, statistical clustering techniques have been utilised to define homogeneous groups of municipalities with respect to the nationality composition of their foreign population as well as the impact of immigration on their size and demographic characteristics.
\end{abstract}

\section{Introduction}

Greece is a country with a long migration history. Since the 19th century until the early 1980s, the Greek population exhibited an intensive emigration profile. Towards the end of the 19th century, Greek emigrants moved to urban areas in the Balkan parts of the Ottoman Empire, to Istanbul, to the coastal areas of Asia Minor and to Egypt. By the end of the 19th century a substantial number of Greeks (about 2.5 million), mostly from the rural areas of the central and western parts of the country, emigrated to the United States of America (USA), resulting in a $15 \%$ to $20 \%$ loss of the native population. After the end of World War II a

\footnotetext{
* Anastasia Kostaki (author of correspondence), Department of Statistics, Athens University of Economics and Business, Patission 76, 10434, Athens, Greece. Email: kostaki@aueb.gr

Byron Kotzamanis, Department of Planning and Regional Development, University of Thessaly, Laboratory of Demographic and Social Analyses, Volos, Greece.

Michail Agorastakis, Department of Planning and Regional Development, University of Thessaly, Laboratory of Demographic and Social Analyses, Volos, Greece.
} 
second wave of emigration took place where two major flows could be distinguished. One wave flow was that of political refugees that migrated towards the former Soviet Union (USSR) and other eastern European countries and of the second wave flow consisted of economic emigrants, approximately 1.3 million until the early 1970s, and these emigrants moved towards the USA, Canada, Australia and the highly industrialised countries of western European, specifically West Germany. Throughout the following period, 1980-90, the country experienced an inflow of returning Greeks from both east and west. At the same time, an inflow of immigrants, in addition to the Greek returnees, began. Initially they were Asian and African economic immigrants, and then, followed by immigrants from the ex-socialist countries of eastern Europe, especially from Albania and, to a lesser degree from the other Balkan countries, as well as from the countries of the former USSR. Subsequently, Greece, in a short period of time and very quickly, changed from a traditional sending country to a receiving country. According to the 1981 census, the number of foreigners ${ }^{1}$ was approximately 180,000 , corresponding to almost $2 \%$ of the total counted population; 20 years later, in the 2001 census, the foreign population that was counted, increased to $762,000,7 \%$ of the total population.

The considerable change in the migration profile of Greece has led to a significant amount of literature (e.g. Petronoti and Triandafyllidou 2003 and www.antigone.gr/bibliography.html). In most of these analyses, the demographic and spatial dimension of the phenomenon is often omitted and the foreign population is considered as a single group at the country level. However, some research has been carried out on these aspects, (e.g. Baldwin-Edwards 2008; Kaklamani and Androulaki 2006; Kotzamanis and Alvanides 2005; Kotzamanis et al. 2006; Kotzamanis and Pilidis 2006; Kotzamanis and Kostaki 2007, 2008; Kotzamanis 2009; Tsimbos 2006, 2008).

Since the immigrant population is neither uniformly distributed spatially, nor even proportional to the native population, and consists of various nationality groups with significantly different demographic behaviours, the examination of the implications of immigration on the population size and structure at a low geographical level, according to the nationality composition of the foreign population, might be useful in finding structures which are impossible to observe otherwise. This paper examines the impact of immigration on the population size and the demographic characteristics of the population in Greek municipalities. In order to do this, statistical clustering techniques have been utilised to define homogeneous groups of municipalities by the nationality composition of their foreign population and the impact of immigration on the size, age and sex distribution of the population. Section 2 provides a description of the demographic characteristics of the foreign population in Greece and its spatial dispersion. In Section 3 the implications of immigration on the population size

$1 \quad$ People with other than Greek nationality. 
and the demographic characteristics of Greek municipalities are examined. Finally, a summary of the findings of our analysis and some concluding remarks are provided in Section 4.

\section{The demographic characteristics of the foreign population in Greece}

For the purpose of our analysis foreigners have been classified according to their nationality into four major groups: i) Group 1, individuals originating from more developed countries; ${ }^{2}$ ii) Group 2, individuals from Balkan countries; iii) Group 3, individuals from eastern European ex-socialist countries, excluding Balkan countries, including ex-USSR countries; and iv) Group $4,{ }^{3}$ from the less developed countries. As presented in Table 1 in the Appendix, the foreign population in Greece in 1981 was approximately 180,000, corresponding to less than $2 \%$ of the total population, while $65 \%$ of the foreigners originated from the more developed countries, i.e. 34\% from the European Union countries (EU-15 countries, i.e., all the EU members prior to the 2004 enlargement), $11 \%$ from the Republic of Cyprus, $13.5 \%$ from the USA and 6.5\% from Australia and Canada. A decade later, the proportion of foreigners from Group 1 significantly diminished, while foreigners from Groups 2 and 3 exhibited a significant increase (up to $15.8 \%$ and $15.1 \%$, respectively). In 2001 , foreigners in absolute numbers increased by four times their 1981 count, reaching 762,000 or $7 \%$ of the total population which was approximately 11 million. Moreover, their nationality composition also drastically altered. In the 2001 census, the dominance of Group $2(65.7 \%)$ over Group $1(13.1 \%)$ is evident for the total number of foreigners.

\subsection{The population structure of foreigners}

As expected, the foreign population exhibits a significantly different demographic profile in comparison to the native population. As can be seen from the population pyramids Figure 1the age and sex structure of the foreigners significantly differs from that of the natives, the former exhibiting a much younger age composition than the latter and a sex distribution in favour of males for Groups 2 and 4 and in favour of females for the other two nationality groups. In addition, the differences between the age and sex distribution of Greeks and foreigners according to the 2001 census are striking (see Table 2 in the Appendix).

According to the United Nations (UN) definition.

According to the UN definition. 
Figure 1:

Population pyramids by nationality group
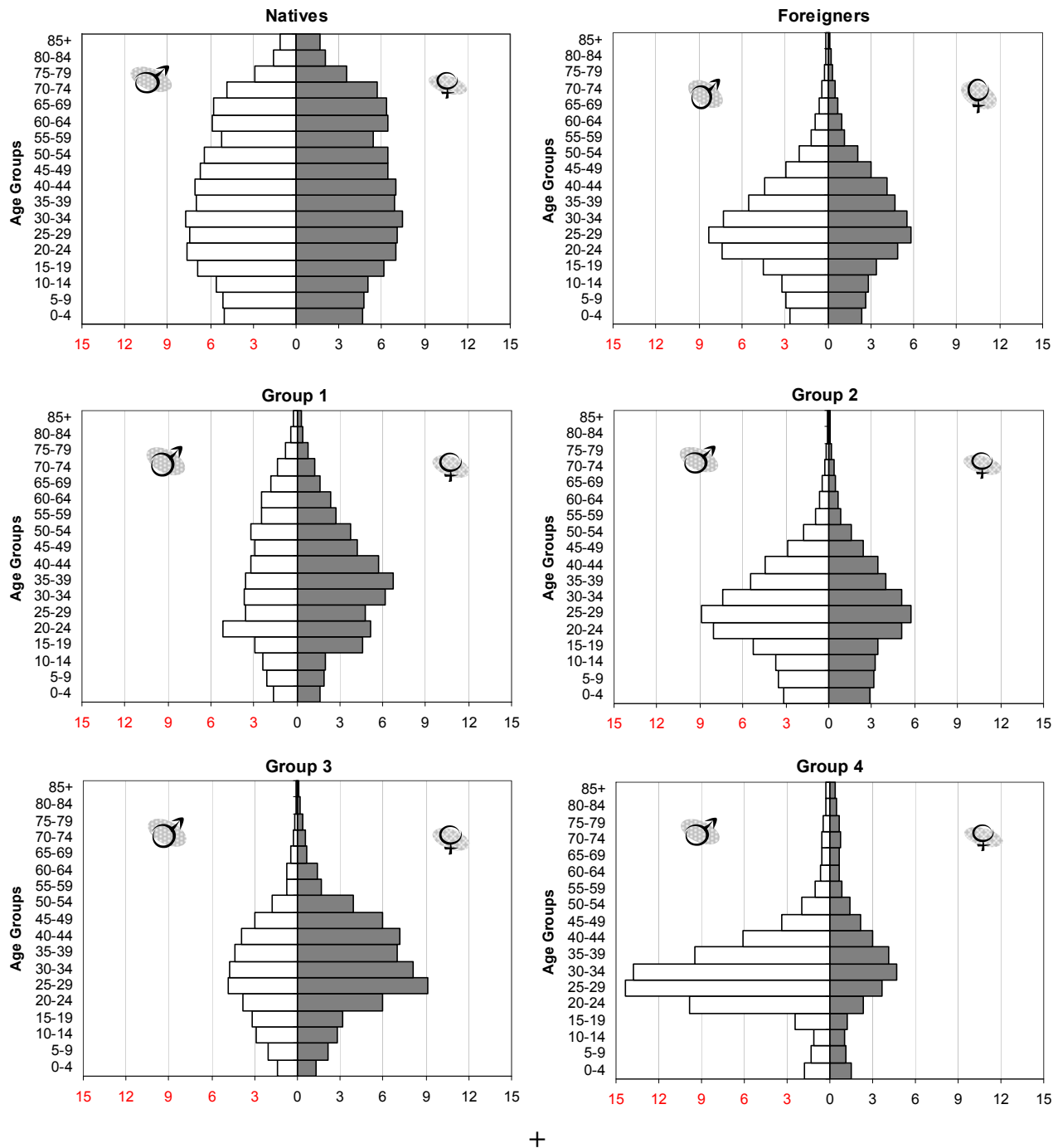

Source: Authors' computations.

When comparing the pyramids of the various country groups, striking differences are observed in their age and sex structures. For Greeks the distribution of the two sexes is relatively balanced (49.1\% versus $50.9 \%$ ), the slight predominance of females being exclusively attributed to differences in the mortality levels between the two sexes. For the foreign population there is a reverse relationship between the two sexes ( $54.5 \%$ males versus $45.5 \%$ females). 
Moreover, there are striking sex differences among the various nationality groups of foreigners; the percentage of males for Group 4 is more than $69 \%$, while for Group 3 it is as low as $38 \%$. The values of the sex ratio are also indicative, being 83 for the overall foreign population recorded in 2001, 160 for the foreigners of Group 3, 75 for Group 2 and 45 for Group 4. These notable imbalances between the two sexes are directly related to the socio-economic conditions and the differentiated roles of men and women, on the one hand in the countries of origin, and on the other to their migration strategies.

We can therefore deduce that the demographic profiles of Greeks and foreigners are significantly different. Foreigners are characterised by younger age structures, their median age being 10 years younger than that of the Greeks and the proportion of people over the age of 65 being much lower. With regard to their sex distribution, males clearly outnumber females, in contrast with the native population. Nevertheless, the consequences of immigration on the demographic structures of the population in Greece at a national level are not striking, as the overall percentage of foreigners in the total population is low; the presence of foreigners in the population led to a slight increase in the percentage of males $(+0,4 \%)$, a slight drop in the percentage of people older than $65(-1 \%)$ and the mean age $(-0,7$ years) as well as to a slight increase in the proportion of the age group 15-64 in the total population $(+1 \%)$.

\subsection{The spatial dispersion of foreigners}

At the municipality level, the spatial dispersion of foreigners is slightly different from that of Greeks (Table 1), as the values of Gini coefficients are 0.842 for the former and 0.739 for the latter. However, foreigners from the less developed countries, as well as those coming from the ex-socialist countries exhibit higher concentrations (the Gini index is equal to 0.971 and 0.911 , respectively), in contrast to those coming from the Balkan countries (the Gini coefficient is equal to 0.827 ).

Table 1:

Values of the Gini indices for the various population subgroups

\begin{tabular}{lc}
\hline \multicolumn{1}{c}{ Population Groups } & Gini coefficient \\
\hline Total population & 0.744 \\
Natives & 0.739 \\
Foreigners & 0.842 \\
Group 1: Developed countries & 0.889 \\
Group 2: Balkan) & 0.827 \\
Group 3: Eastern European countries & 0.911 \\
Group 4: Less developed countries & 0.971 \\
\hline
\end{tabular}

Source: Author's computations based on data from the 2001 Census, NSSG (2001). 
Differences in the concentration of foreigners in municipalities, reflected in the values of Gini indices, are associated with the differences in the percentage of foreigners in their total population. ${ }^{4}$ As illustrated in Figure 2, there are very few units, with no foreigners (28 out of 1,034), while, in others, foreigners make up more than $10 \%$ of their total population (165 out of 1,034 , which is $16.3 \%$ of the total population of the country). The latter units are located in the more economically developed areas of the country, i.e. in the major urban centres of continental Greece, in the coastal zone of the Peloponnesus, on islands, which are agricultural and/or have been developed for tourism, and the areas neighbouring Albania.

\section{Figure 2:}

Percentage of foreigners in the total population (data from the 2001 census)

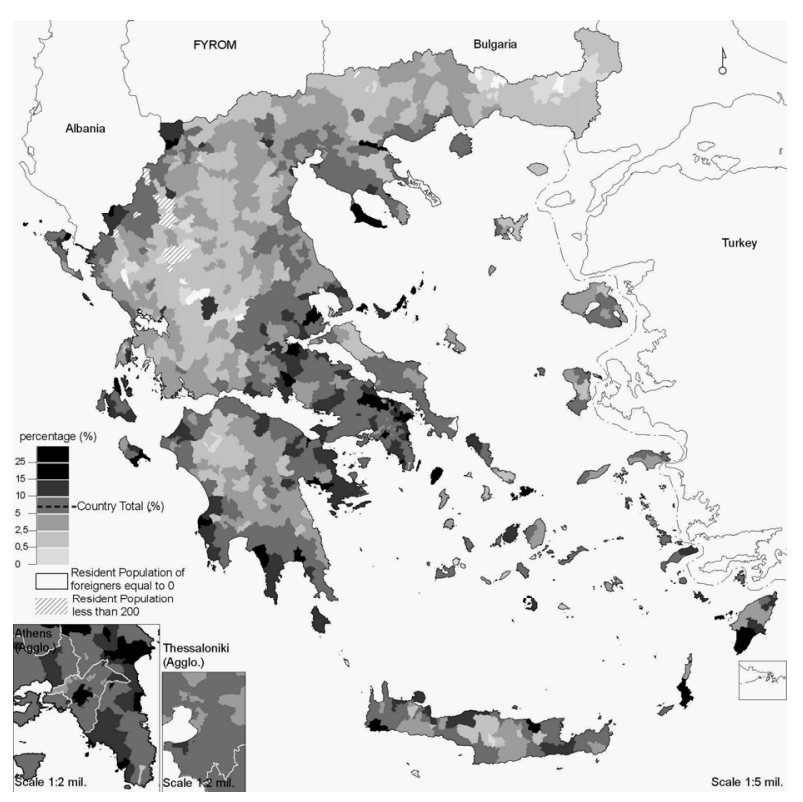

Source: Authors' computations.

4 For the purpose of our analysis we use population data for the 1034 municipalities of Greece provided by the 2001 population census. Municipalities with a population of less than 200 inhabitants (28 units), those without foreigners (10 units), and Mount Athos have been excluded from the analysis. The population of the excluded municipalities does not exceed 12 , 000 people, i.e. less than $0.1 \%$ of the total counted population of Greece. It should be also noted here that in the 2001 census, the count of foreigners is slightly lower, Lianos et al (2008). However, the failure rates were differentiated by country of origin; the immigrants from Asian and African countries were highly underestimated, and to a lesser degree people from some countries of Eastern Europe especially Poland. More details of the quality of the 2001 census data, are given in Baldwin-Edwards and Kyriakou (2004) and Baldwin-Edwards (2009). 
Figure 3, illustrating the values of the location quotient ${ }^{5}$ (LQ), highlights differences in the spatial concentration of foreigners. Although Figure 3 provides a similar picture to Figure 2, Figures $3 \mathrm{a}, 3 \mathrm{c}$ and $3 \mathrm{~d}$ illustrate significantly different patterns. From these figures it can be seen that in a limited number of municipalities, the values of $\mathrm{LQ}^{6}$ for foreigners coming from the more developed, the ex-socialist and the less developed countries (Groups 1, 2 and 4, respectively) are exceptionally high. Taking as a criterion index values greater than 1.8 (this means that, in municipalities which are characterised by these values, the percentage of foreigners of the examined group of countries in the total population of foreigners of these municipalities is 1.8 times higher than the percentage of foreigners of the same group of countries in the total foreign population of the country), we observe in Figure 3d, that these municipalities are almost exclusively located in places north of the greater metropolitan area of Athens while in contrast, foreigners coming from the ex-socialist countries (Figure 3c), are concentrated in central and eastern Macedonia and in Thrace. Furthermore, people coming from the Balkan countries have a roughly balanced spatial distribution (Figure 3b), with corresponding values of LQ being slightly higher in the eastern part of central Greece and the municipalities neighbouring Albania, while these are almost absent in Thrace (LQ values tending to 0 ). Finally, by examining Figure 3a, we observe that people from more developed countries are highly concentrated on the islands where tourism is highly developed and in the northern high income suburbs of the Athens agglomeration, as well as in the sparse municipalities of continental Greece characterised, in recent decades, by a high level of development for tourism, which experienced a strong emigration during the early post war years. From all the above it is evident that, as the distribution of the total population of foreigners at municipality level does not significantly differ from that of Greeks, their influx has not changed the pre-existing highly unequal population distribution. It should also be noted that the impact of immigration on the population size and the demographic characteristics in municipalities depends on the one hand on the percentage of foreigners in their total population and on the other hand on the nationality synthesis of the foreigner population in each municipality.

5 LQ is calculated as [(population of foreigners in each municipality/total population of the same municipalities)]/ [(population of foreigners in Greece/total population of Greece)]. If its value equals one it means that the percentage of foreigners in the specific municipality is the same as the percentage of foreigners in the total population of the country. If its value is less than one, the percentage of foreigners in the specific municipality is higher than that of the country and vice versa.

6 Here, LQs are calculated as follows: [(population of foreigners from country group $\mathrm{x}$ in each municipality/total population of foreigners in the same municipalities)]/[(population of foreigners from country group $\mathrm{x}$ in the total population of Greece/total population of foreigners in Greece)]. 
Figure 3:

Location quotient for immigrants at the municipality level (2001 census)

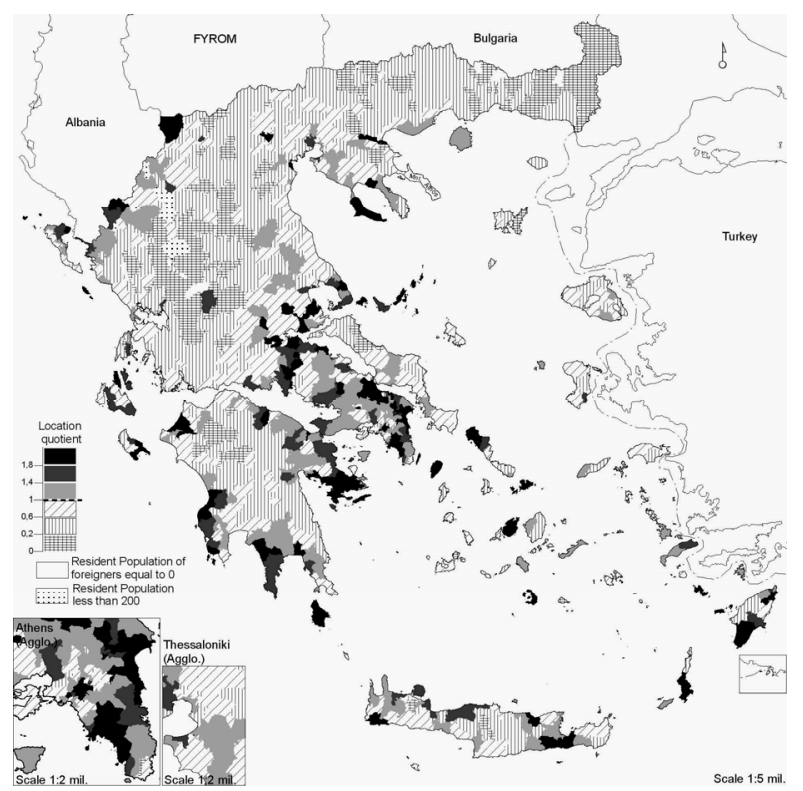

Source: Authors' computations.

Figure 3a:

Location quotient for country Group 1 immigrants at the municipality level

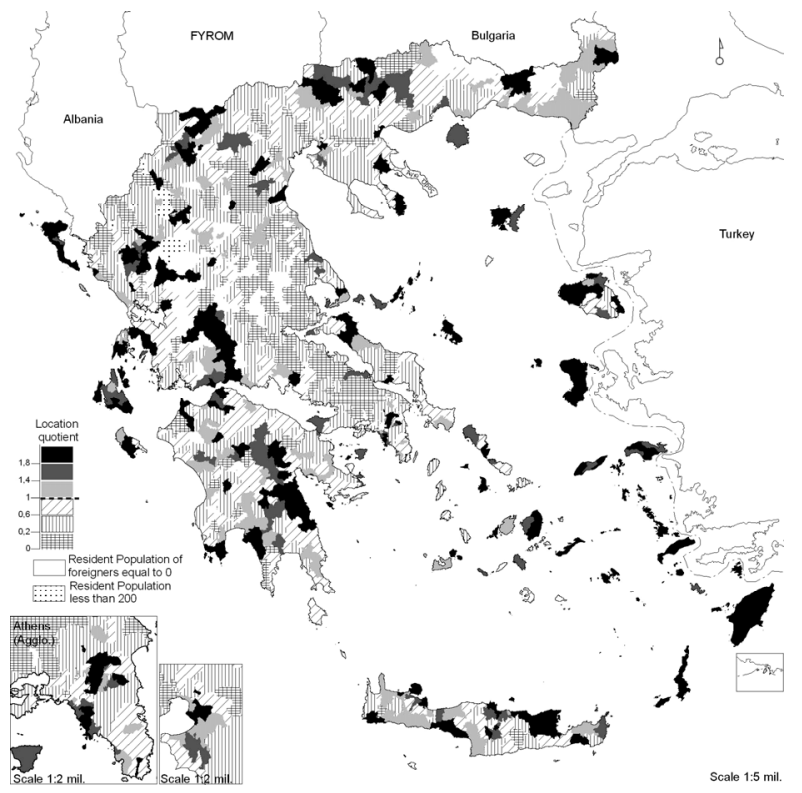

Source: Authors' computations. 
Figure 3b:

Location quotient for country Group 2 immigrants at the municipality level

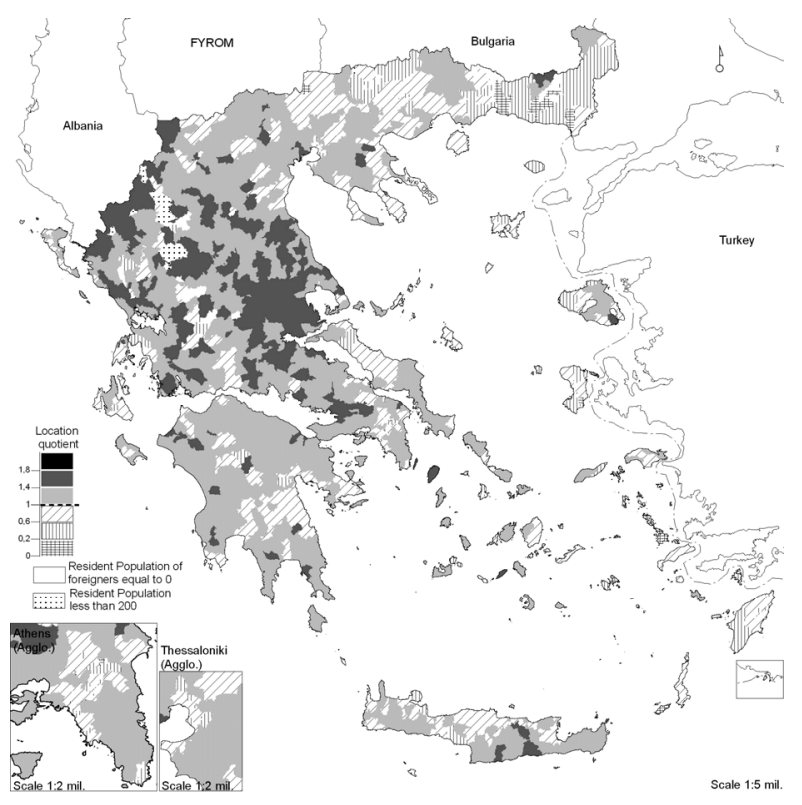

Source: Authors' computations.

Figure 3c:

Location quotient for country Group 3 immigrants at the municipality level

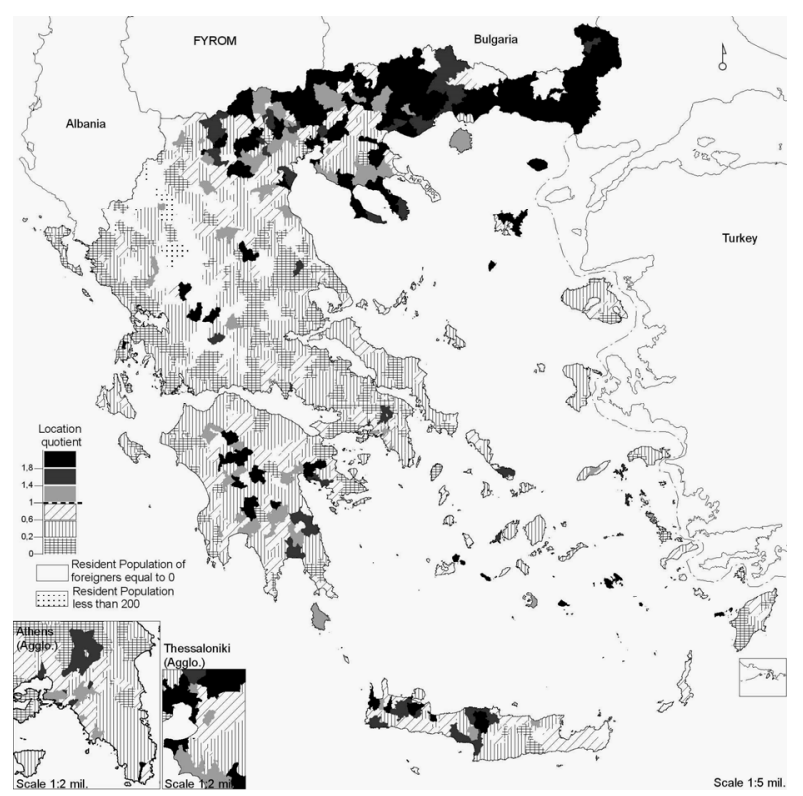

Source: Authors' computations. 
Figure 3d:

Location quotient for country Group 4 immigrants at the municipality level

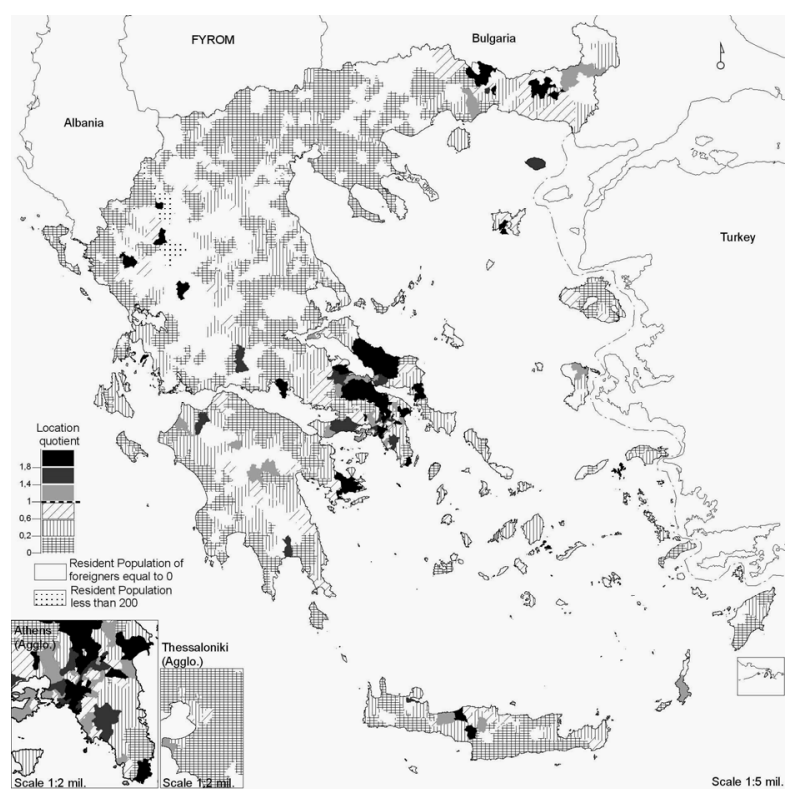

Source: Authors' computations.

\section{The implications of immigration on the population size and the demographic characteristics of municipalities in Greece}

\subsection{Data and methods}

As previously mentioned, for the purpose of our analyses, population data are used for the 995 municipalities of Greece provided by the 2001 population census. $^{7}$ At first an identification of homogenous groups of municipalities, according to the nationality synthesis of their immigrant populations is attempted. For that we calculate the percentage of immigrants for each of the four nationality groups of foreigners previously defined, and then using the two-step clustering statistical procedure, we classify municipalities into homogenous groups

\footnotetext{
In our analyses, census data for the years 2001, for some investigations 1991, were used, conducted by the National Statistical Service of Greece referring to the usual resident population differentiated by sex, age, nationality and place of residence. People who do not have Greek nationality are considered to be foreigners. Foreigners who received Greek nationality during the period 1991 to 2001 (a very limited number, since according to Greek law naturalisation is extremely limited), and people with dual nationality one being Greek, are registered as Greeks in the 2001 census.
} 
according to their foreign population nationality structure. Thereafter, in an attempt to estimate the implications of immigration on the age and sex structure of the population, in each municipality we consider the Greek population, i.e. the population that would be if immigration had never taken place, as well as the total population, i.e. the actual population that is made up of both Greeks and foreigners. Then, for the two populations, in every municipality, we calculate the differences between the values of various characteristics reflecting the sex and age composition of the population. The characteristics examined are the proportion of males, the mean age of the population, the proportion of population in the active age group and the proportion of females of reproductive age. Thereafter, according to the magnitude of the differences of these proportions, we classify the municipalities into homogenous groups using statistical criteria based on the size of these differences. In order to reveal the optimal grouping of the municipalities into homogenous groups according to the alternative characteristics listed above, we utilise the two step statistical clustering procedure ${ }^{8}$ that we used before, which is an exploratory statistical tool designed to reveal natural grouping in a dataset that would otherwise not be apparent.

\subsection{Municipality profiles according to the nationality synthesis of the immigrants}

According to the results of the clustering technique used, the municipalities are classified into five distinct homogenous clusters according to the nationality synthesis of the immigrant population in them. Table 2 presents the results of this classification, while Figure 4 provides an illustration of it.

If we consider the values in Table 2 we conclude that, in the majority of municipalities (Cluster 4, 50.3\%), people from the Balkan countries form the overwhelming majority of their immigrant population, their mean percentage in these municipalities being equal to $87.9 \%$, which is significantly higher that their country mean of $71.8 \%$. In these areas, the presence of people from the more developed countries is much lower than their mean presence in the country as a whole $(5.5 \%$ as compared to the country mean of $14.4 \%)$, while the two other groups are also significantly underrepresented. In Figure 4 we observe that these municipalities are located in inland Greece (except central and eastern Macedonia, Thrace, the eastern part of the Peloponnesus and most of the islands).

Furthermore, another group of municipalities (Cluster 1, 8.4\%) exhibit a very high number of people from more developed countries and a lower number of people from the Balkan and eastern European countries. These municipalities are mostly located in the eastern Aegean islands and Crete as well as in the northern suburbs of the Athens agglomeration. Another group (Cluster 5, 24.1\% of the

\footnotetext{
${ }^{8}$ The analysis is implemented in the SPSS statistical package.
} 
total number of Greek municipalities) is characterised by the immigrants from the Balkan and eastern European countries that is slightly smaller compared with their country mean, and a much higher number of people from the more developed countries ${ }^{9}$ in comparison again with their country mean. From Figure 4, we can easily observe that these municipalities are located mostly in the eastern part of the Peloponnesus, on Crete, the Ionian Islands and Cyclades, as well as, in the northern and eastern suburbs of Athens.

Table 2:

Nationality composition of the different municipality profiles

\begin{tabular}{ccccccccc}
\hline Cluster & $\begin{array}{c}\text { No. of } \\
\text { municipalities }\end{array}$ & $\mathbf{( \% )}$ & $\begin{array}{c}\text { \%o of total } \\
\text { population }\end{array}$ & $\begin{array}{c}\text { \% of } \\
\text { foreigners }\end{array}$ & \multicolumn{3}{c}{$\begin{array}{c}\text { Mean percentage } \\
\text { Group } \mathbf{1} \text { Group 2 Group 3 Group 4 }\end{array}$} \\
\hline $\mathbf{1}$ & 84 & 8.4 & 4.0 & 4.0 & 51.7 & 32.9 & 6.7 & 8.7 \\
$\mathbf{2}$ & 53 & 5.3 & 7.6 & 3.8 & 13.5 & 31.2 & 52.1 & 3.2 \\
$\mathbf{3}$ & 118 & 11.9 & 24.0 & 33.2 & 9.2 & 64.5 & 22.7 & 3.6 \\
$\mathbf{4}$ & 500 & 50.3 & 35.0 & 31.4 & 5.5 & 87.9 & 3.8 & 2.7 \\
$\mathbf{5}$ & 240 & 24.1 & 29.4 & 27.5 & 22.8 & 64.0 & 6.2 & 7.0 \\
\hline Combined & $\mathbf{9 9 5}$ & $\mathbf{1 0 0 . 0}$ & $\mathbf{1 0 0 . 0}$ & $\mathbf{1 0 0 . 0}$ & $\mathbf{1 4 . 4}$ & $\mathbf{7 1 . 8}$ & $\mathbf{9 . 4}$ & $\mathbf{4 . 5}$ \\
\hline
\end{tabular}

Note : Means at the end of the last four columns are calculated as the arithmetic means of the percentage of immigrants of each nationality group.

Source: Authors' computations.

A small number of municipalities (Cluster 2, 5.3\%) have a much higher number of people from eastern European countries (more than five times their country mean) and a somewhat lower number of people from the Balkans and less developed countries. These municipalities are almost solely in Thrace, which is located nearest to their countries of origin. Finally, $11.9 \%$ of the municipalities (Cluster 3) are characterised by people from the Balkan countries which is slightly lower compared with their country mean and also by a high level of immigrants from eastern Europe (more than double their country mean) while the other two nationality groups of immigrants have a lower level than their country mean. These municipalities are mainly located in central and eastern Macedonia, areas that are closer to their countries of origin, and to a lesser degree, in the central Peloponnesus and western Crete.

$9 \quad$ In this municipality group, the percentage of those coming from the less developed countries (country Group 4) is also limited (half of their country mean, 7\% versus 10\%). 
Figure 4:

Municipality profiles according to the nationality synthesis of the immigrants

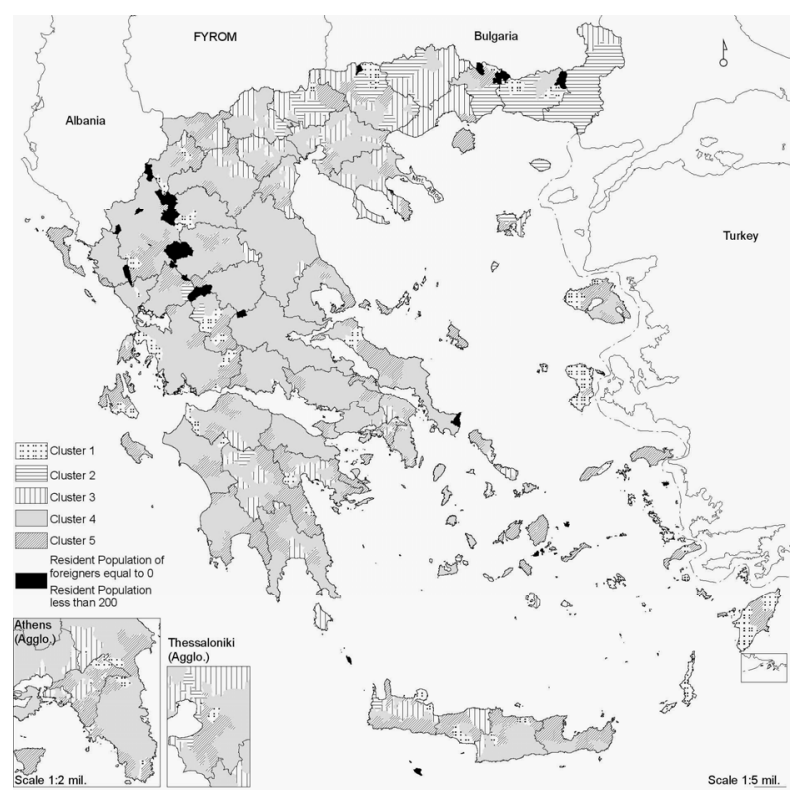

Source: Authors' computations.

\subsection{The implications of immigration on the population size of municipalities}

In order to estimate the impact of immigration on the change of population size in Greek municipalities, we used data from the 1991 and 2001 censuses and classified municipalities according to the magnitude of the differences between the total population change and the corresponding change in the native population only, between 1991 and 2001. Table 3 illustrates the results of this classification. A total of 437 municipalities ( $43.9 \%$ of the Greek municipalities, $44 \%$ of the total population) experienced a mean decrease in their population size by $9.8 \%$. If these municipalities had not experienced any immigration during the period 1991 and 2001 , this decrease would be equal to $12.9 \%$. For 433 municipalities $(43.5 \%$ of all municipalities, $59 \%$ of the total population) the mean increase in their population size was equal to $24.3 \%$, while without immigrants this increase would be equal to $17.4 \%$. The most striking finding here was that 125 municipalities (126\% of the total, and $9.5 \%$ of the total population) experienced a population increase of $8 \%$, without immigrants these municipalities would have experienced a population decrease of $4 \%$. Figure 5 provides an illustration of the geographical location of the municipalities in these three groups. 
Table 3:

Mean changes in the population size between 1991 and 2001

\begin{tabular}{|c|c|c|c|c|c|c|c|c|}
\hline Impact & $\begin{array}{l}\text { Number } \\
\text { of muni- } \\
\text { cipalities }\end{array}$ & $(\%)$ & $\begin{array}{c}\% \text { of total } \\
\text { popula- } \\
\text { tion }\end{array}$ & $\begin{array}{c}\% \text { of } \\
\text { foreigners }\end{array}$ & $\begin{array}{c}\text { Foreigners } \\
\text { in total } \\
\text { population } \\
(\%) \\
\end{array}$ & $\begin{array}{c}\text { Mean } \\
\text { change in } \\
\text { native pop. } \\
\text { size (\%) }\end{array}$ & $\begin{array}{c}\text { Mean } \\
\text { change in } \\
\text { total pop. } \\
\text { size (\%) }\end{array}$ & $\begin{array}{l}\text { Differences } \\
\text { in mean } \\
\text { changes }\end{array}$ \\
\hline Negative & 437 & 43.9 & 32.2 & 37.6 & 8.1 & -12.9 & -9.8 & 3.1 \\
\hline Positive & 433 & 43.5 & 58.5 & 51.1 & 8.5 & 17.4 & 24.3 & 6.9 \\
\hline $\begin{array}{l}\text { Sign } \\
\text { alteration }\end{array}$ & 125 & 12.6 & 9.4 & 11.3 & 6.1 & -4.0 & 8.0 & 120 \\
\hline Combined & 995 & 100.0 & 100.0 & 100.0 & 7.0 & & & \\
\hline
\end{tabular}

Source: Authors' computations.

Figure 5:

The impact of immigration on changes in the population size between 1991 and 2001

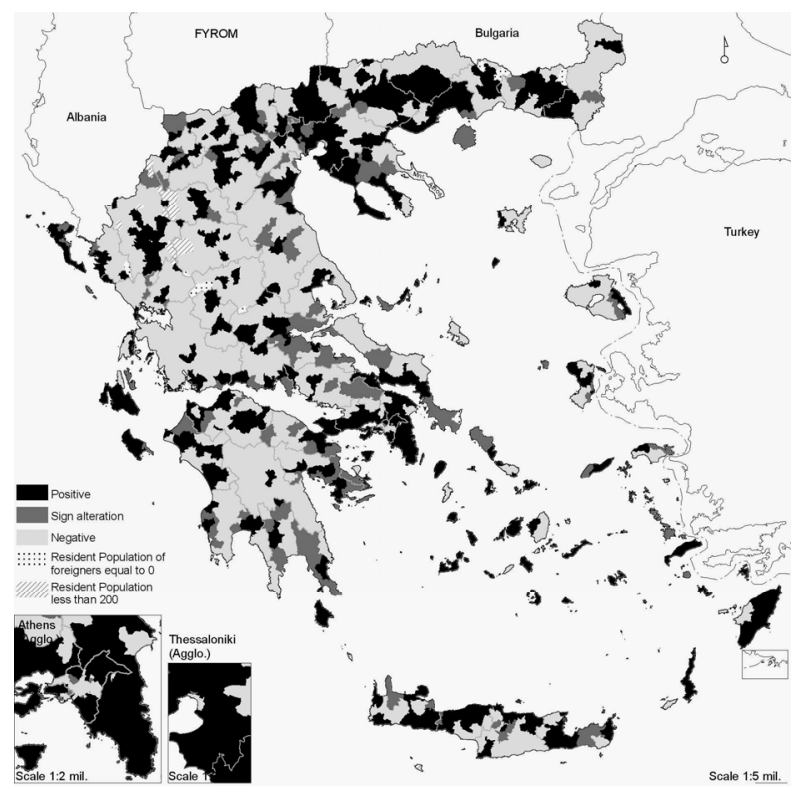

Source: Authors' computations.

Obviously, the municipalities that were affected most by immigration with regard to their size were those located in the greater metropolitan areas of Athens and Thessalonica and the surrounding areas, in the coastal areas of Peloponnesus, on Crete and some other islands, as well as, in areas near the Albanian border. Therefore, we conclude that the massive inflow of foreigners into Greece significantly enhanced the human capital of the country and, to a great extent, both the demographic vigour of most municipalities, which experienced positive 
changes during the period 1991-2001, and the significant deceleration in population decline in half of the municipalities in which negative changes were recorded throughout that decade. Furthermore, on the one hand, foreigners contributed to a deceleration in population decline in most of the Greek municipalities and on the other hand, they contributed to the demographic enhancement of the most dynamic geographical unities of the country.

\subsection{The contribution of foreigners to changes in the sex and age structure of the population in Greek municipalities}

In Section 2.1, when we examined the demographic structures of foreigners at the national level and compared them to the corresponding structures of the native population, we highlighted differences between the two groups, as well as among the four nationality groups of foreigners. We also concluded that the demographic impact of immigration has been relatively limited at this overall level. Nevertheless, it should be interesting to examine the immigration impact on the population at a low spatial level, i.e. the municipality level. An analysis at this level allows us to examine the potential differentiated impacts that probably underlie the national averages.

\subsubsection{Implications of immigration on the sex structure of the population}

In order to estimate the influence of foreigners on the sex distribution of the population, we classified municipalities according to the differences in the percentage of males between the actual and the native population in each municipality. Figure 6 illustrates the results of this classification. The rough picture that emerges in the map is that, in all municipalities, foreigners have contributed to an increase in the percentage of men in their population. Nevertheless, the impact of immigrants on the sex structure of the population in municipalities exhibits significant variations related to the unequal spatial distribution of foreigners as well as to differences in their nationality structure. According to the magnitude of the differences in the proportion of males between the total population and the Greek population, the municipalities can be classified into three homogenous groups. Figure 6a provides an illustration of the $95 \%$ confidence intervals for the mean increase of the male proportions in each group. According to the results of our clustering procedure presented in Table 4 in 33 municipalities (Cluster 1, 3.3\%) immigration resulted in a statistically highly significant increase in the percentage of males, with a mean increase equal to 3.7 
percentage units, ${ }^{10}$ while in another group (Cluster 2, 19\%) immigration resulted in a lower, although statistically significant, increase in the percentage of males, with a mean increase equal to 1.3 percentage units. However, in $78 \%$ of the municipalities (Cluster 3), immigration has not exhibited any statistically significant increase, the mean increase in the percentage of males being equal to 0.2 and their variability, as indicated by the value of the standard deviation, is very high. The municipalities in Clusters 1 and 2 are mainly concentrated on either side of the central road axis linking the south-western part to the northern part of the country and also near the border with Albania. In the majority of these municipalities the percentage of foreigners in the total population is clearly higher than the national mean (13\% to $155 \%$ versus $7 \%$ ) and in addition, there is a high concentration of foreigners from the less developed countries which is characterised by a very low number of women.

\section{Figure 6:}

Classification of municipalities according to the impact of immigration on the percentage of males

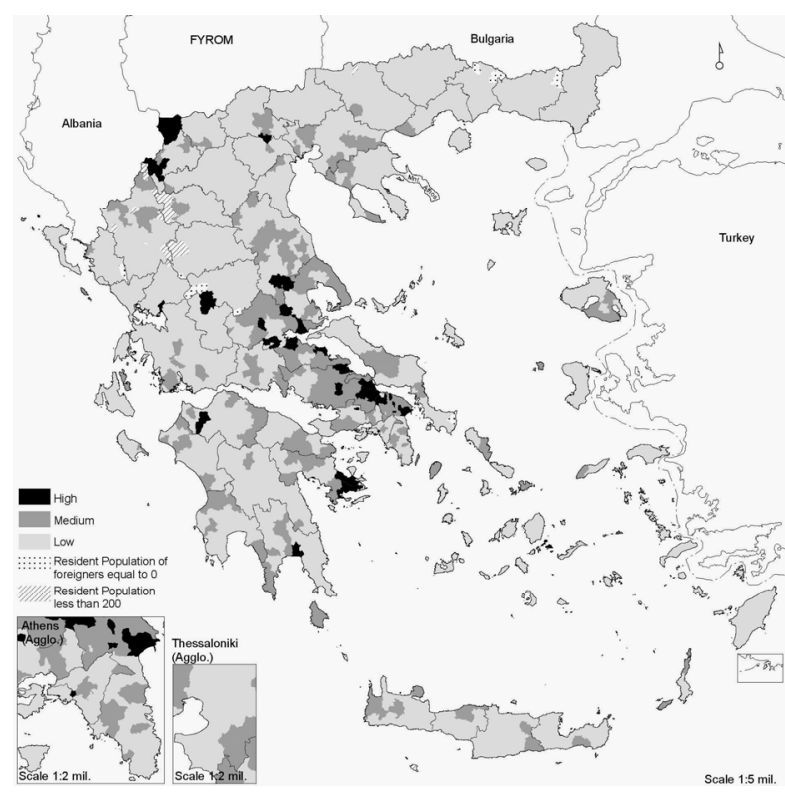

Source: Authors' computations

10 The significant changes in the sex distribution of this group are dependant on the extremely high percentage ( $21 \%$ versus $10 \%$ at the national level) of foreigners from the less developed countries where males represent $70 \%$. 
Table 4:

Classification of municipalities according to the impact of immigration on the percentage of males

\begin{tabular}{|c|c|c|c|c|c|c|c|c|c|c|}
\hline \multirow[t]{2}{*}{ Cluster } & \multirow{2}{*}{$\begin{array}{c}\text { No. of } \\
\text { munici- } \\
\text { palities }\end{array}$} & \multirow[t]{2}{*}{$(\%)$} & \multirow{2}{*}{$\begin{array}{c}\text { Mean } \\
\text { difference } \\
(\%)\end{array}$} & \multirow{2}{*}{$\begin{array}{c}\% \text { of } \\
\text { total } \\
\text { popula- } \\
\text { tion } \\
\end{array}$} & \multirow{2}{*}{$\begin{array}{c}\% \text { of } \\
\text { foreign- } \\
\text { ers }\end{array}$} & \multirow{2}{*}{$\begin{array}{c}\text { Foreigners } \\
\text { in total } \\
\text { population } \\
(\%) \\
\end{array}$} & \multicolumn{4}{|c|}{ Percentage } \\
\hline & & & & & & & 1 & 2 & 3 & 4 \\
\hline$\overline{1 H}$ & 33 & 3 & & 1.4 & & 15.4 & 2.8 & 73. & 3 & 20 \\
\hline 2 Mediuı & 18 & 18.8 & & 17. & 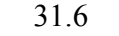 & 12 & 8. & 67 & 1 & 13 \\
\hline 3 Low & 11 & 77.9 & 0.2 & 81.4 & 65.4 & 5. & 15.8 & 64.3 & 12. & 7.6 \\
\hline Combined & 995 & 100.0 & 0.5 & 100.0 & 100.0 & 7.0 & 13.1 & 65.7 & 11.3 & 9.9 \\
\hline
\end{tabular}

Source: Authors' computations.

Figure 6a:

Simultaneous $95 \%$ confidence intervals for the mean percentage of males

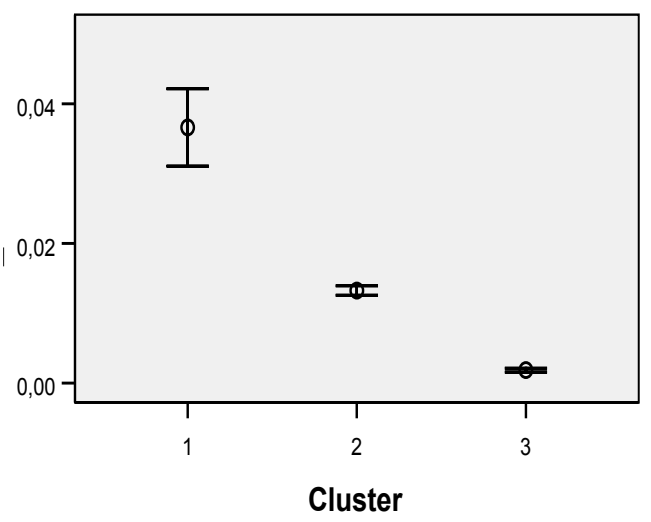

Source: Authors' computations.

\subsubsection{Implications of immigration on the age structure of the population}

Despite the significant differences in the age structure among the four nationality groups of foreigners, their population as a total is notably younger than the Greek population, as the mean age of the former is almost 10 years younger than of the latter (30.9 versus 40.6 years old, see Table 2 in the Appendix). This difference in mean age is mainly attributed to the extremely young age structure (mean age 287 years) of foreigners from the Balkan countries, which make up the majority (66\%) of the total foreign population. Given the ageing tendencies of the native population in Greece, it is essential to examine the implications of the massive inflow of young foreigners on the mean age of the population in the municipalities, as well as on the population of the active age group (15-64 years old). 
With regard to mean age, the inflow of foreigners, as expected, resulted in a drop of the mean age of the total population in all municipalities (Figure 7). This drop is clearly spatially differentiated. If we look at the magnitude of the differences in the mean age between the native population and the total population in each municipality, the impact of immigration is striking. The municipalities were been classified into three homogenous groups. According to the results of our clustering procedure presented in Table 5, in 427 municipalities (Clusters 1 and 2) or $43 \%$ of all municipalities, comprising $36 \%$ of the total population and $64 \%$ of foreigners, immigration resulted in a statistically significant decrease in the mean age- by 2.10 years for 115 municipalities and by about one year for the other 312 . Figure 7 a provides an illustration of the $95 \%$ confidence intervals of the mean values of these differences. It is clearly observable in Figure 7, which illustrates the geographical distribution of these municipalities, that the most extreme changes in the mean age of the population took place in municipalities located in the central east and the southern parts of continental Greece, on some islands, as well as, in municipalities located near the Albanian border. The municipalities of these two groups are usually characterised by a high percentage of foreigners in their total population and/or by a particularly high number of foreigners from the Balkan countries. However, in the majority of the Greek municipalities (57\%), comprising the $64 \%$ of the total population but only $28 \%$ of foreigners, particularly those of the over-aged municipalities of mountainous continental Greece, immigration has not resulted in any statistically significant decrease of the mean age, as the mean increase has been very low.

Table 5:

Classification of municipalities according to the impact of immigration on the mean age

\begin{tabular}{|c|c|c|c|c|c|c|c|c|c|c|}
\hline Cluster & $\begin{array}{l}\text { No. of } \\
\text { munici- }\end{array}$ & $(\%)$ & $\begin{array}{l}\% \text { of } \\
\text { total }\end{array}$ & $\begin{array}{c}\% \text { of } \\
\text { foreign- }\end{array}$ & Foreig- & $\begin{array}{c}\text { Mean } \\
\text { difference }\end{array}$ & Group & $\begin{array}{l}\text { Perc } \\
\text { Group }\end{array}$ & $\begin{array}{l}\text { ntage } \\
\text { Group }\end{array}$ & p \\
\hline & palities & & non & ers & $\begin{array}{c}\text { total } \\
\text { pop. }(\%)\end{array}$ & $\begin{array}{c}\text { In mean } \\
\text { age (years) }\end{array}$ & 1 & 2 & 3 & 4 \\
\hline $1 \mathrm{H}$ & & 11 & 11. & & 16.4 & -2.1 & & $6 t$ & 10 & 14.7 \\
\hline $2 \mathrm{~N}$ & 312 & 31 & & 28 & 8.2 & -1 & 11.6 & 72 & 7.7 & 8.1 \\
\hline 3 Low & 568 & 57.1 & 64.0 & 75.1 & 4.8 & -0.3 & 16.7 & 60.8 & 14.4 & 8.1 \\
\hline Combined & 995 & 100.0 & 100.0 & 100.0 & 7.0 & -0.8 & 13.1 & 65.7 & 11.3 & 9.9 \\
\hline
\end{tabular}

Source: Authors' computations. 


\section{Figure 7:}

Clustering of municipalities according to the impact of immigrants on the mean age

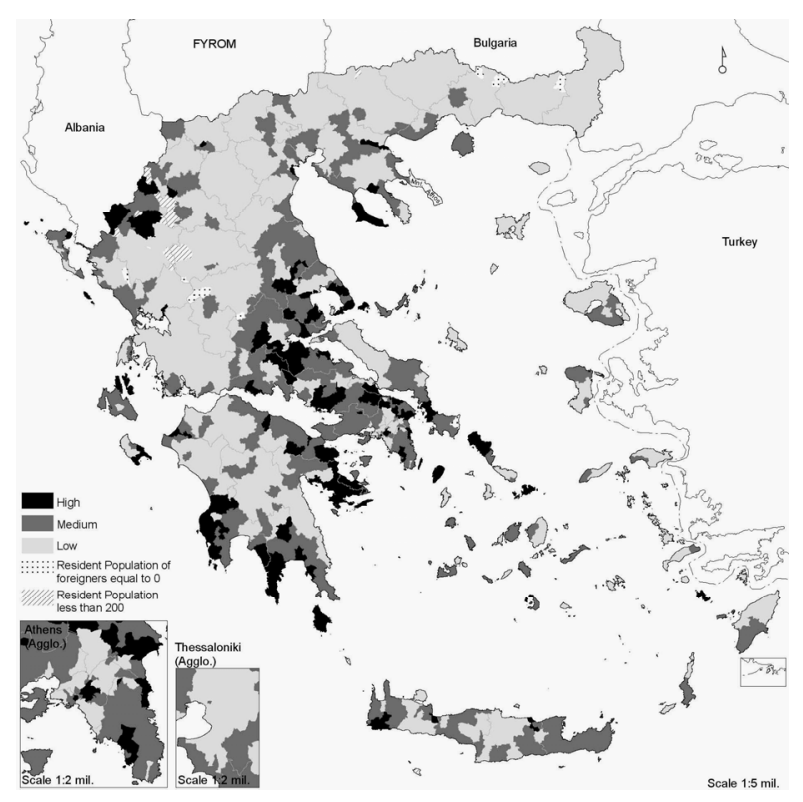

Source: Authors' computations.

\section{Figure 7a:}

Simultaneous $95 \%$ confidence intervals for the mean age

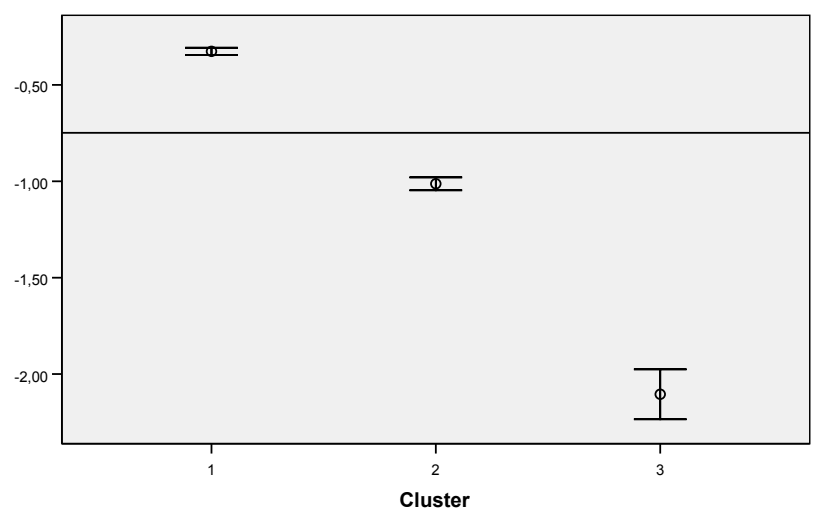

Source: Authors' computations.

If we look at the population in the active age group (Table 6), in half of the municipalities (Cluster 4) or $49 \%$ of all municipalities, comprising $57 \%$ of the total population and $38 \%$ of the total foreign population, the impact of foreigners is insignificant, and in 288 municipalities (Cluster 3) it is relatively limited. In 
contrast, in 221 municipalities (Clusters 1 and 2, almost 25\% of the total number of municipalities of Greece, containing almost $20 \%$ of the total population), the impact of foreigners on the population in the active age group, is relatively strong. In some of them (Cluster 1, 39 units with a population sizes ranging from 2000 to 10,000 , which is only $155 \%$ of the total population), the impact of immigration is highest, as foreigners were responsible for an increase in the population in the age group 15-64 of an average of 5.5\%.

The municipalities of these two clusters are located in the eastern continental part of Greece, on some islands (particularly in the Cyclades, on Rhodes and on Crete), and at the border with Albania. Furthermore, if we compare Figure 8 with Figure 1, which illustrates the level of immigrants in the population of Greek municipalities, we observe that the results are roughly the same. This is because the majority of the municipalities in which foreigners contributed significantly to the increase in the percentage of population in the active age group, are also those in which the percentage of foreigners in the total population are more than double the national mean.

\section{Figure 8:}

Impact of immigrants on the percentage of the population in the active ages group

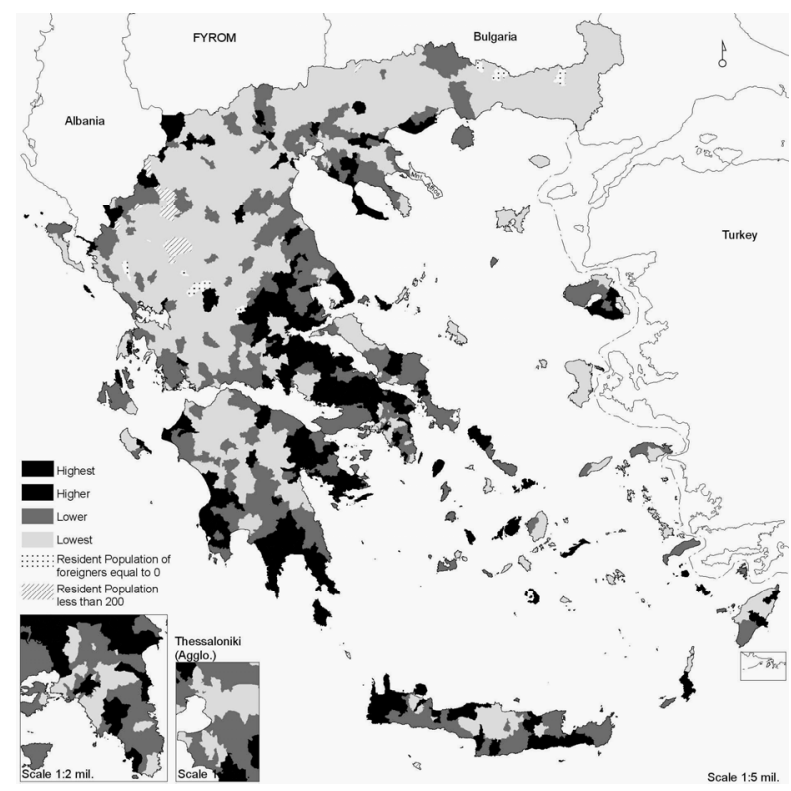

Source: Authors' computations. 
Figure 8a:

Simultaneous $95 \%$ confidence intervals for the mean percentage of the population in the active ages

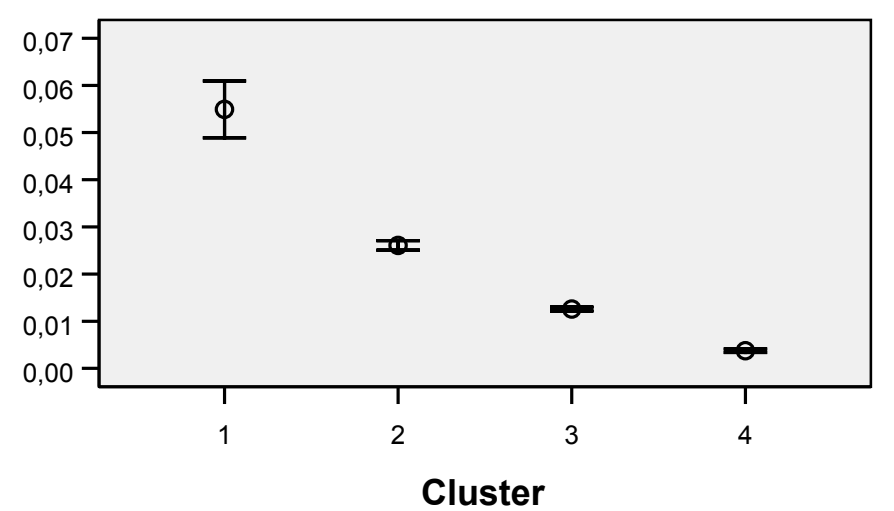

Source: Authors' computations

Table 6:

Classification of municipalities according to the impact of foreigners on the percentage of the population in the active age group

\begin{tabular}{|c|c|c|c|c|c|c|c|c|c|c|}
\hline \multirow[b]{2}{*}{ Cluster } & \multirow{2}{*}{$\begin{array}{c}\text { No. of } \\
\text { munici- } \\
\text { palities }\end{array}$} & \multirow[b]{2}{*}{$(\%)$} & \multirow{2}{*}{$\begin{array}{c}\text { Mean } \\
\% \\
\text { in } \\
\text { cluster }\end{array}$} & \multirow{2}{*}{$\begin{array}{l}\text { \% of } \\
\text { total } \\
\text { pop. }\end{array}$} & \multirow[b]{2}{*}{$\begin{array}{c}\% \text { of } \\
\text { foreigners }\end{array}$} & \multirow{2}{*}{$\begin{array}{c}\% \\
\text { foreigners } \\
\text { in total } \\
\text { pop. } \\
\end{array}$} & \multicolumn{4}{|c|}{ Percentage } \\
\hline & & & & & & & $\begin{array}{c}\text { Group } \\
1\end{array}$ & $\begin{array}{c}\text { Group } \\
2\end{array}$ & $\begin{array}{c}\text { Group } \\
\mathbf{3}\end{array}$ & $\begin{array}{c}\text { Group } \\
4\end{array}$ \\
\hline 1 Highest & 39 & 3.9 & 5.5 & 1.5 & 3.5 & 15.8 & 5.0 & 80.2 & 4.0 & 10.8 \\
\hline 2 Higher & 182 & 18.3 & 2.6 & 17.5 & 33.4 & 13.3 & 9.9 & 65.9 & 10.5 & 13.7 \\
\hline 3 Lower & 288 & 28.9 & 1.3 & 23.8 & 24.7 & 7.2 & 13.2 & 68.6 & 9.3 & 8.9 \\
\hline 4 Lowest & 486 & 48.8 & 0.1 & 57.2 & 38.5 & 4.7 & 16.6 & 62.4 & 13.8 & 7.3 \\
\hline Combined & 995 & 100.0 & 0.9 & 100.0 & 100.0 & 7.0 & 13.1 & 65.7 & 11.3 & 9.9 \\
\hline
\end{tabular}

Source: Authors' computations.

\subsubsection{Implications of immigration on the population of women of reproductive age}

The implications of foreigners on the total population of women of reproductive age (15-49 years old), taking into consideration their disproportional sex distribution, are limited. Given the unequal spatial distribution of foreigners, as well as the high differences among the sex distributions of the four nationality groups (see Table 2 in the Appendix), strong differentiations are expected and recorded at municipality level (Figure 9). Thus, in a small group of municipalities (Clusters 1 and 2, comprising 222 municipalities, which form $22 \%$ of the total number of municipalities) the foreign women of reproductive age have contributed to an increase of more than $24 \%$. Those municipalities that are more affected comprise only $17 \%$ of the total population and $36 \%$ of foreigners 
(Table 7). These municipalities (Figure 9) have some common characteristics; the percentage of foreigners in the total population is usually more than double national average and their contribution to the sex distribution is, for the majority, insignificant.

\section{Figure 9:}

The impact of immigrants on the percentage of females of reproductive age

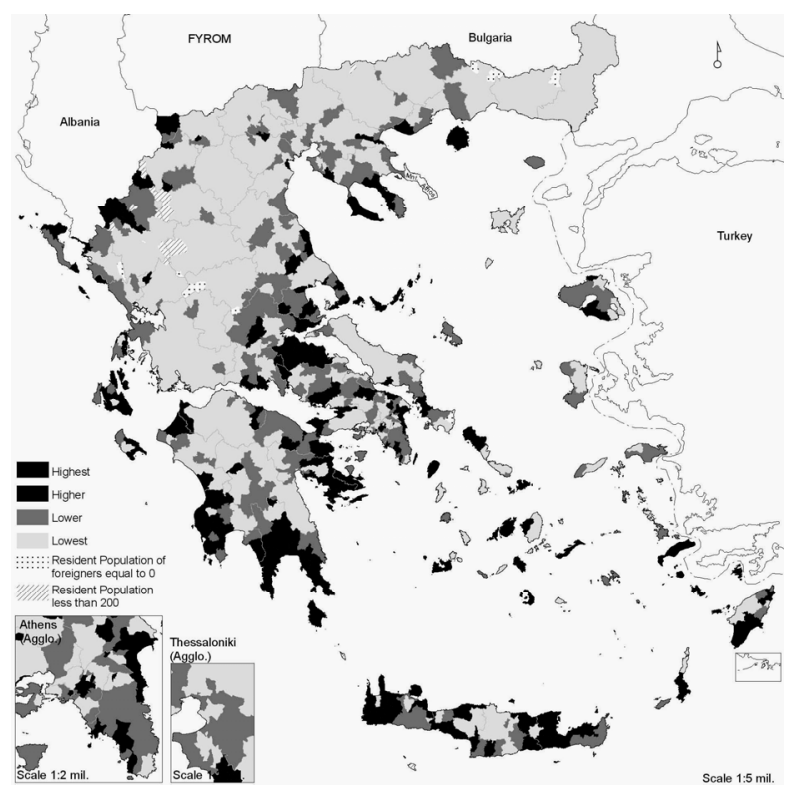

Source: Authors' computations.

Figure 9a:

Simultaneous $95 \%$ confidence intervals for the mean percentage of females of reproductive age

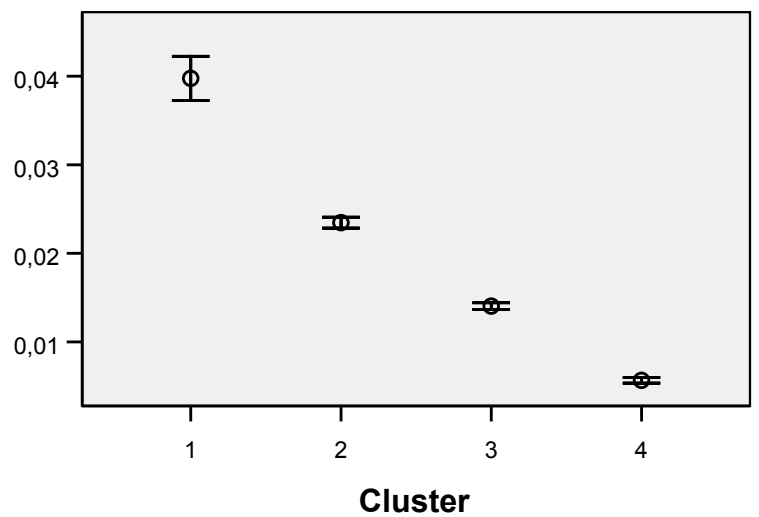

Source: author's computations 
Table 7:

Classification of municipalities according to the impact to women of reproductive age

\begin{tabular}{lcccccc|cccc}
\hline Cluster & $\begin{array}{c}\text { No. of } \\
\text { munici- } \\
\text { palities }\end{array}$ & $\begin{array}{c}\text { (\%) } \\
\end{array}$ & $\begin{array}{c}\text { Mean } \\
\text { \% } \\
\text { cluster }\end{array}$ & $\begin{array}{c}\text { \%o of } \\
\text { total } \\
\text { pop. }\end{array}$ & $\begin{array}{c}\text { \%o of } \\
\text { foreign- } \\
\text { ers }\end{array}$ & $\begin{array}{c}\text { Foreigners } \\
\text { in total } \\
\text { pop. (\%) }\end{array}$ & \multicolumn{4}{c}{ Percentage } \\
Group & Group Group Group \\
$\mathbf{1}$ & & & $\mathbf{2}$ & $\mathbf{3}$ & $\mathbf{4}$ \\
\hline 1 Highest & 69 & 6.9 & 4.0 & 10.2 & 24.2 & 16.5 & 10.8 & 63.4 & 11.2 & 14.5 \\
2 Higher & 153 & 15.4 & 2.4 & 7.6 & 11.9 & 10.8 & 14.7 & 70.9 & 6.6 & 7.9 \\
3 Lower & 236 & 23.7 & 1.4 & 25.7 & 27.8 & 7.6 & 14.5 & 65.2 & 12.5 & 7.8 \\
4 Lowest & 537 & 54.0 & 0.6 & 56.5 & 36.2 & 4.5 & 13.1 & 65.9 & 11.9 & 9.1 \\
\hline Combined & $\mathbf{9 9 5}$ & $\mathbf{1 0 0 . 0}$ & $\mathbf{1 . 3}$ & $\mathbf{1 0 0 . 0}$ & $\mathbf{1 0 0 . 0}$ & $\mathbf{7 . 0}$ & $\mathbf{1 3 . 1}$ & $\mathbf{6 5 . 7}$ & $\mathbf{1 1 . 3}$ & $\mathbf{9 . 9}$ \\
\hline
\end{tabular}

Source: Authors' computations.

\subsubsection{The contribution of foreigners to changes in the demographic structures of Greek municipalities}

Finally, after considering the unequal concentration of foreigners in municipalities and the examination of their impact on the size, sex and age structure of the population of municipalities, we now provide a synthesis taking into consideration the simultaneous impact of immigration on all the population characteristics previously considered, in order to highlight areas throughout the country where immigration had the most simultaneous influence on the population structure. According to the results of the multivariate clustering technique used (Table 8), the municipalities were classified into four clusters. We initially observed that in a large cluster of municipalities (446 out of 995) the implications were insignificant while in another large group (302 out of 995) these were low. These two clusters contain $81 \%$ of the total population. However, in 138 municipalities ( $7 \%$ of the total population), the implications of immigration were statistically significant, and in 109 municipalities $(12 \%$ of the total population of the country), these implications were very significant. Figure 10 illustrates this classification. It is obvious that the municipalities strongly affected are concentrated mostly in the eastern lowland part of central Greece, in the eastern and south-western part of the Peloponnesus and at the border with Albania. The high percentage of foreigners in these municipalities can to some extent, explain the significance of the impact of immigration on them. However, this is not the sole reason as reflected in the fact that Figures 1 and 10 do not give exactly the same picture. Another factor associated with the significance of the immigration impact is the nationality synthesis of the foreign population in these municipalities. 
Figure 10:

Clustering of municipalities according to the simultaneous impact of immigrants on the percentage of males, the mean age, the percentage of the population in the active age group and the percentage of females of reproductive age

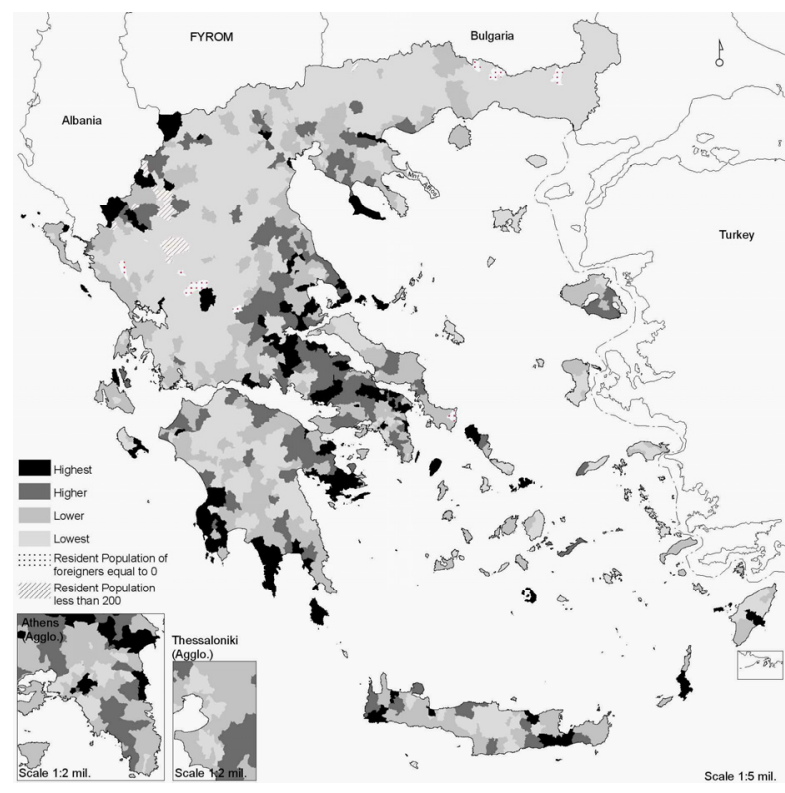

Source: Authors' computations.

Figure 10a:

Simultaneous $95 \%$ confidence intervals for the mean, of the percentage of males, the mean age, the percentage of the population in the active age group and the percentage of females of reproductive age
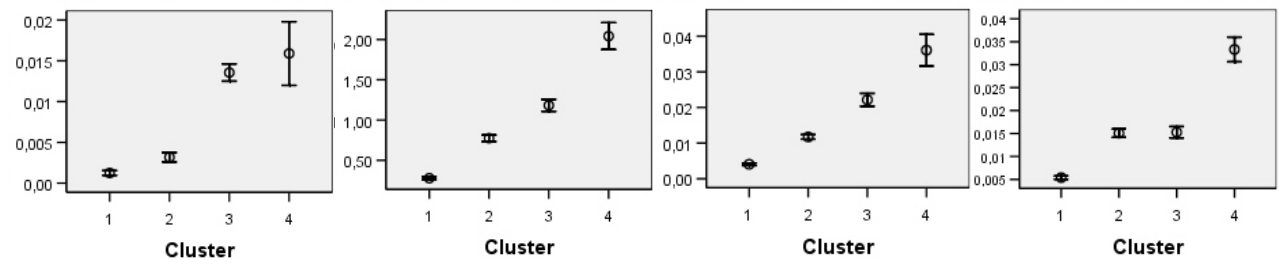

Source: Authors' computations. 
Table 8:

Clustering of municipalities according to the simultaneous impact of immigrants on the percentage of males, the mean age, the percentage of population in active ages and the percentage of females of reproductive age

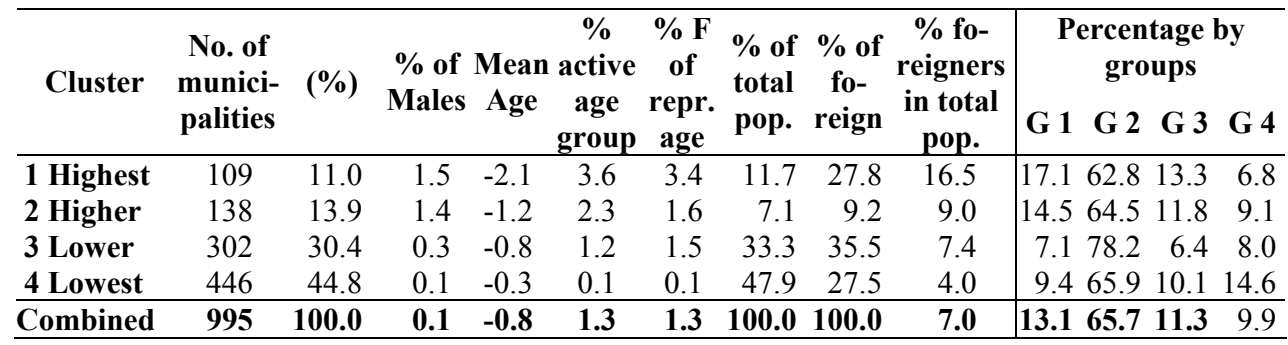

Source: Authors' computations

\section{Concluding remarks and discussion}

Immigration in Greece is an ongoing process that has implications for the demographic, economic, political and social profile of the country. One would expect that the massive influx of immigrants since the early 1990s and given their heterogeneous nationality synthesis and their significantly different demographic profiles would have significantly influenced the demographic structure of the population of Greece. In this paper, using data from the last two population censuses, an analysis of the implications of immigration on the population structure in Greece is discussed. Initially, the basic demographic characteristics of the foreign population, as a total and also differentiated according to nationality, are considered at the national level. It is evident that the massive inflow of foreigners, with a different demographic profile from that of the native population and their unequal spatial distribution throughout country, has affected both the population size as well as the sex and age distribution of the total population.

However, the impact of immigration at the national level is limited; the massive inflow has not significantly changed the demographic structure overall. Immigration has led to a very slight change in the sex distribution of the population in favour of males, in a decrease in the percentage of the population older than 64 years by $1 \%$, as well as a lowering in the mean age by 0.7 years, a slight increase in the percentage of population in the active age group by $0.9 \%$ and of women of reproductive age by $1.3 \%$. Foreigners show a significantly different geographical concentration and their nationality composition also significantly differs spatially. Therefore, we considered the impact of immigration on the population size and structure and examined it on a smaller spatial scale. The analysis throughout the municipalities, given the significant variations in the concentrations and the nationality synthesis of the foreign population in them, has highlighted patterns of their impact on the population size and structure in neither 
municipalities nor overall. Thus the consideration at this low spatial level led us to conclude that foreigners have determinatively contributed to both the slowing down of population depletion in a large part of the Greek countryside, as well as, to the demographic enhancement of the most dynamic geographic areas of the country.

In addition, given the relatively young male profile of foreigners, their impact to the age distribution of the population of municipalities has been significant, especially in some areas with specific characteristics. In particular in increasing the percentage of males in 220 out of 995 of the municipalities, decreasing the mean age of the population in almost half (427 out of 995), increasing the percentage of the population in the active age group in 221, as well as the percentage of women of reproductive age in 222, Finally, according to the results of our multivariate analysis, a total of 237 municipalities have experienced a statistically significant simultaneous influence on the characteristics examined. Almost all of the affected municipalities are located in the economically developed areas of the eastern part of lowland central continental Greece, in parts of eastern and southwest Peloponnesus and Crete that have been developed for agriculture and tourism, as well as on some Aegean and Ionian islands highly specialised in tourism, and finally at the border with Albania.

We conclude from the findings of the analysis that the massive inflow of foreigners into Greece has brought significant changes in the demographic map of the country. However, these changes are highly differentiated as the dispersion of foreigners according to their nationality characteristics (the various nationality groups of foreigners show great differences in their demographic characteristics) shows significant spatial deviations. Moreover, the findings of this analysis emphasise the necessity for a study of the dimensions of this rather 'new' migration on a small spatial scale, and also highlight the inefficiency of the current approaches at the country level or at greater region levels, since foreigners do not form a homogenous group with common characteristics and concentrations and therefore significant differences in their nationality synthesis and their geographical dispersion should be considered by policy makers in migration policies.

\section{References}

Baldwin-Edwards, M. 2009. “Greece.” In: H. Fassman., U. Reeger., and W. Sievers (eds.) Statistics and reality, Concepts and measurements of Migration in Europe. Amsterdam, Amsterdam University Press, pp. 235-26.

Baldwin-Edwards, M. 2008. "Immigrants in Greece: characteristics and issues of regional distribution." Research Report. Athens, Andreas Papandreou Institute of Strategic and Development Studies (ISTAME). 
Baldwin-Edwards, M. and I. Kyriakou. 2004. "Statistical data for the immigrants in Greece." [In Greek]. Research Report. Athens, IMEPO, Hellenic Migration Policy Institute.

Kaklamani, S. and E. Androulaki. 2006. "Immigration en provenance des Balkans et modification de la structure par sexe et par âge de la population de la Grèce et de ses départements," In: A. Parant (ed.) Migrations, Crises and Recent Conflicts in the Balkans. Volos, Presses Universitaires de Thessalie - Demobalk, pp. 245-266.

Kotzamanis, B. and S. Alvanides 2005: "The spatial distribution of immigrants and their contribution to recent population change in Greece: 1991-2001" 1st European Conference on Population Geographies, 'Population Policies, Institutions and Changing Distributions.' School of Geography, University of Wales. Swansea, UK.

Kotzamanis, B. 2009. "The Demographic implications of the recent immigration inflow in Greece." Paper presented at the Demographic trends and prospects in Greece and in European Union Conference. Athens, Academy of Sciences, 13-14 March 2009.

Kotzamanis B. and A. Kostaki. 2008. "Migration and Migrants in Modern Greece -The Impact of Immigration on the Spatial Structure of the Population in Greece." Paper presented at the European Population Conference organised by the European Association for Population Studies, Barcelona, 9-12 July 2008.

Kotzamanis B. and A. Kostaki. 2007. "The impact of immigration on the population structure of Greece." Paper presented at the Forth International Conference on Population Geographies, Hong-Kong, 10-13 July 2007.

Kotzamanis, B., M. Agorastakis, A. Pilidis, and D. Stathakis. 2006. "Foreigners in Greece, a spatial analysis of their demographic characteristics and of their contribution to population changes during period 1991-2001" [in Greek]. LDSA Discussion papers 6. Volos, University of Thessaly, Department of Planning and Regional Development, Laboratory of Demographic and Social Analyses.

Kotzamanis, B. and A. Pilidis. 2006. "L'immigration en provenance des Balkans et la répartition spatiale de la population en Grèce." In: A. Parant (ed.) Migrations, Crises and Recent Conflicts in the Balkans. Volos, Presses Universitaires de Thessalie LADS/Demobalk, pp. 227-244.

Lianos, T., K. Kanellopoulos, M. Gregou, E. Gemni, and P. Papakonstadinou. 2008. "An estimate of the volume of foreigners that reside illegally in Greece" [in Greek]. Research Report from AENEAS Project, Athens.

National Statistical Service of Greece (NSSG). 2001. Results of the 18 March 2001 population and housing census. Athens.

Petronoti, M. and A. Triandafyllidou. 2003. "Recent immigration flows to Greece." Working papers 2003/2. Athens, National Centre of Social research \& National Book Centre.

Tsimbos, C. 2008. "Net Migration Estimates for Greece by age, sex and citizenship, 19912001." Migration Letters 5(2): 189-202.

Tsimbos, C. 2006. "The Impact of Migration on Growth and Ageing of the Population in a New Receiving Country: the Case of Greece." International Migration 44(4): 232-254. 


\section{Appendix}

Table A1:

Population distribution according to nationality in different census years $(1981,1991$ and 2001)

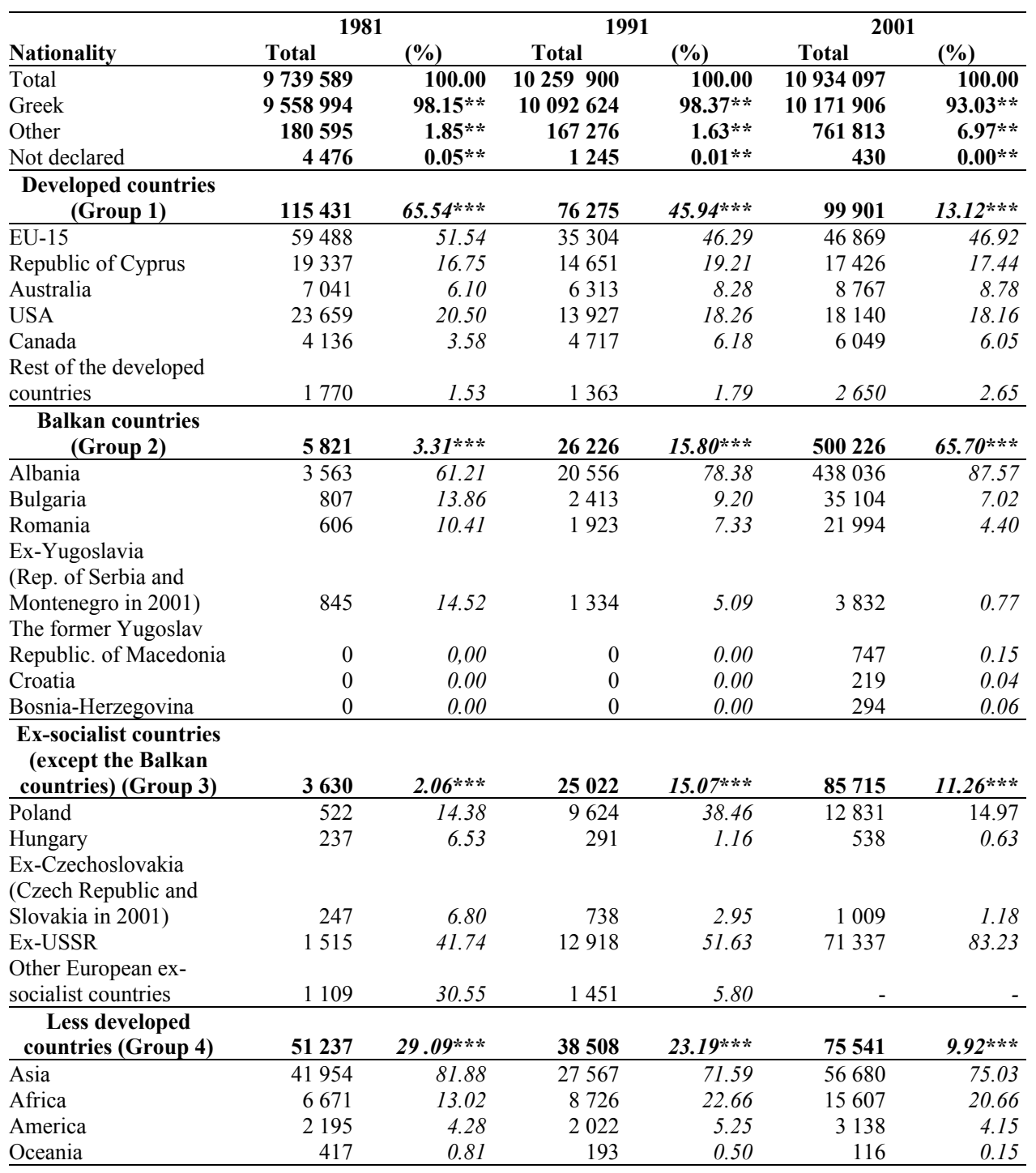

Notes:

*Those who declared an additional nationality (Greek and another country were included in the Greek group).

**Percentage in the total population.

***Percentage of the population that declared their nationality.

In italic - percentage of individuals of a given nationality to the total of the group.

Source: Kotzamanis et al. (2006). 
Table A2:

Demographic characteristics within population groups, according to the 2001 Census

\begin{tabular}{|c|c|c|c|c|c|c|c|c|c|c|c|c|c|c|c|c|}
\hline & Total & $(\%)$ & Males & $\begin{array}{c}\text { Males } \\
(\%)\end{array}$ & Females & $\begin{array}{c}\text { Females } \\
(\%)\end{array}$ & $\begin{array}{l}\text { Sex } \\
\text { ratio }\end{array}$ & $0-14$ & $\begin{array}{l}0-14 \\
(\%)\end{array}$ & $15-64$ & $\begin{array}{c}15-64 \\
(\%)\end{array}$ & $65+$ & $\begin{array}{l}65+ \\
(\%)\end{array}$ & $\begin{array}{c}\text { Females } \\
(15-49)\end{array}$ & $\begin{array}{c}\text { Females } \\
(15-49) \\
(\%)\end{array}$ & $\begin{array}{c}\text { Mean } \\
\text { age } \\
\text { (years }\end{array}$ \\
\hline Total & 10934097 & 100 & 5413426 & 49.51 & 5520671 & 50.49 & 101.98 & 1660899 & 15.19 & 7445965 & 68.10 & 1827233 & 16.71 & 2726150 & 49.38 & 39.93 \\
\hline Natives & 10172284 & 93.03 & 4998058 & 49.13 & 5174226 & & 103.52 & 1534088 & 15.08 & 6837640 & 67.22 & 1800556 & 17.70 & 445 & 48.07 & 40.60 \\
\hline Foreigners & 761813 & 6.97 & 415368 & 54.52 & 346445 & 45.48 & 83.41 & 126811 & 16.65 & 608325 & 79.85 & 26677 & 3.50 & 238705 & 68.90 & 30.90 \\
\hline D & & & & 0.38 & & & & & 0.11 & & 0.88 & & -0.99 & & 1.31 & -0.67 \\
\hline Group & 99901 & 1 & 43840 & 4388 & 56061 & 56.12 & 8 & & 1147 & 7 & 79.50 & 9024 & 9.03 & S & 66.64 & 37.45 \\
\hline Group 2 & 500226 & 65.66 & 285941 & 57.16 & 214285 & 42.84 & 74.94 & 98530 & 19.70 & 390296 & 78.02 & 11400 & 2.28 & 146198 & 68.23 & 28.72 \\
\hline Group 3 & 85715 & 11.25 & 32979 & 38.48 & 52736 & 61.52 & 159.91 & 10794 & 12.59 & 72437 & 84.51 & 2484 & 2.90 & 39839 & 75.54 & 33.42 \\
\hline Group 4 & 75541 & 9.92 & 52285 & 69.21 & 23256 & 30.79 & 44.48 & 5990 & 7.93 & 65790 & 87.09 & 3761 & 4.98 & 16045 & 68.99 & 33.86 \\
\hline
\end{tabular}

Note: $\mathrm{D}$ is calcuted by substracting the indices of the total population from that of the natives,

under the hypothesis that if no foreigners were present then the two indices (total and native) would be equal.

Source: Kotzamanis (2009). 